\title{
The Use of Portfolio as an Assessment Tool in the Malaysian L2 Classroom
}

\author{
Charanjit Kaur a/p Swaran Singh \\ Faculty of Educational Studies, University Putra Malaysia, 43400 Serdang, SELANGOR \\ Tel: 0126635068 E-mail: charanjitt_06@yahoo.com
}

Arshad Abdul Samad

Faculty of Educational Studies, University Putra Malaysia, 43400 Serdang, SELANGOR

Tel: $0122987424 \quad$ E-mail: arshad.samad@yahoo.com

Received: November 29, 2012 Accepted: December 10, 2012 Published: December 12, 2012

doi:10.5296/ijele.v1i1.2851 URL: http://dx.doi.org/10.5296/ijele.v1i1.2851

\begin{abstract}
This article focuses on the use of portfolio as an assessment tool for learning in two Malaysian secondary ESL classrooms. Participants included nine experienced lower and upper secondary school classroom ESL teachers who had utilised portfolio as an assessment tool in their classrooms. A qualitative research design was employed within the interpretive research paradigm as to provide an in-depth description of ESL teachers' understanding of the use of portfolio as an assessment tool in the classroom. The interview data were used for triangulating data obtained from the classroom observations. Data collected through both techniques were transcribed and analyzed manually. The nine ESL teachers reported that student's self-reflection and self-assessment helped them to improve their instruction in the classroom. Moreover, the ESL teachers found students showed progress in learning via supplementary exercises which were assessed and then graded. The teachers disclosed that the core features of a portfolio assessment include purpose, content and structure which were considered crucial to bring about effective results of student learning. The qualitative findings contribute to a better understanding of the use of portfolio as an assessment tool and have some implications for teaching and assessment.
\end{abstract}

Keywords: Portfolio, Portfolio Assessment, Alternative Assessment 


\section{Introduction}

The concern for students' achievement in English has received a lot of attention. The problem of mastering English does not involve students alone. The English language teachers are also affected. Thus, teachers have resorted to alternative assessment as a means to modify their teaching and make learning more meaningful in the classroom. Teachers of English as a second language have begun to use portfolios a non-traditional form of assessment as a means of gathering information on their students to examine achievement, effort, improvement and the process of self-assessment. While many proposals have been made on how portfolios can be implemented, there is a need to seek teachers' views on the use of portfolio as an assessment tool in the classrooms. A major driving force in improving the teaching and learning of English is the assessment system. While traditional exams are still popular, present day scholars have turned their attention to alternative type assessment to provide more valid and reliable information on student progress and achievement (Tunku Mohani Tunku Mohtar, 2010).

Therefore new methods of assessment have been developed to exhibit what students learn and their ability to use their existence knowledge to facilitate their own learning in the classroom. These new methods of assessment are known as 'alternative assessment' measures (Coombe, 2004). At present, portfolio is viewed as one of the leading alternative assessment approach (Tabatataei, 2012). Portfolios demonstrate students' progress, achievement and self-reflection in one or more areas (Paulson \& Paulson, 1991). Portfolio assessment is an on-going process which involves a procedure which teachers use to plan, collect and analyse a collection of student's work. The main aims of portfolio assessment are to encourage learners to be more autonomous, be independent learners by taking charge of their own learning, able to make decisions, participate in the self-assessment process of their own work, and become active learners (Tabatataei, 2012). Besides student's active participation during the portfolio assessment process, teachers role as a facilitator is considered crucial as they are the key to successful use of such a strategy (Neimon, 1999). Portfolio assessment transforms the role of teacher away from the traditional assessment as one-shot and indirect tests with no feedback toward improving student progress via feedback, self-assessment and self-reflection (Abdul Samad, $2004 \&$ Tabatataei, 2012). Thus, using portfolio as an assessment tool instead of the traditional tests may help teachers to make better judgment and record student learning and at the same time teachers be able to improve their teaching practices.

\section{Review of Literature}

\subsection{Alternatives in Assessment}

Huerta-Macias (1995) points out that alternative assessment are non-intrusive in the sense that they are merely tasks that students do in class every day and students are evaluated on these tasks. Furthermore, 'alternative assessment offer information not only on learners' weaknesses, but also on their strengths, as they are manifested in class over time' (Norris, Brown, Hudson \& Yoshioka, 1998:2). There are several forms of alternative assessment; performance assessment, portfolios, self-assessments, peer-assessment, diaries and student-teacher conferences. In addition to the performance of problem-solving tasks, 
portfolio assessment has become another alternative measure to multiple choice for determining how well students understand and apply concepts (Nezakatgoo, 2011). Marx (2001) suggests portfolio-based assessment as means of individualized, student-centered evaluation has the potential to improve the complex task of student assessment, as well as to contribute to a more positive attitude toward the educational process. Herman, Aschbacher, and Winters (1992:6) classify six characteristics of alternative assessments which are:

-ask students to perform, create, produce, or do something.

-use tasks that represent meaningful instructional activities.

-invoke real-world applications.

-tap higher-level thinking and problem-solving skills.

-require new instructional and assessment roles for teachers.

-use human judgments, and not machine scoring.

\subsubsection{Portfolio and Portfolio Assessment}

According to Simon and Forgette-Giroux (1994), a portfolio is defined as a cumulative and continuous collection of entries selected and reflected on by students in order to assess their competency development. Barrett (2001) defines portfolio as a purposeful collection of students' works exhibiting students' effort, progress, and achievement in one or more areas. Paulson, Paulson, and Meyer (1991) provided an extensive definition of portfolio. They define a portfolio as a purposeful collection of students' work, not only displaying students' effort, progress, and achievement, but also demonstrating students' participation in selecting contents and selecting the criteria for assessment.

Portfolio assessment is beneficial in the sense that it leaves students chance to reflect upon their development, growth, and progress over time (Wang, \& Liao, 2008). It offers teachers teachers an opportunity to think about their students' problems comprehensively (Nolet, 1992). Resisting the shortcomings of standardised examinations, portfolio assessment reflects the "strength, needs, and individuality" of each unique student (Steward, 1993, p. 522). To sum up, portfolio assessment entails the procedure used to plan, collect, and analyse the various types of products kept in the portfolio (Tunku Mohani Tunku Mohtar, 2010). Portfolio assessment stimulates students' learning motivation and facilitates students' learning process (Paulson, et al., 1991; Nolet, 1992; Cole, Struyk, Kinder, Sheehan, \& Kish, 1997). As opposed to the conventional tests which have been not only summative in nature but also norm-referenced, portfolio assessment offers a more accurate reflection of students' learning (Dutt-Doner \& Gilman, 1998; Steward, 1993). Portfolio assessment is valuable as it enable students to think critically, and also become active, independent and self-regulated learners (Bergman, 1994 \& Tunku Mohani Tunku Mohtar, 2010). Being independent learners, students can take responsibility for their own learning (Ballard, 1992). Students are actively engaged in their work and they understand the purpose of doing it. In other words, students are able to develop their ability to self-assess and thus understand their strengths and weaknesses in learning. Portfolio assessment helps students build up their self-confidence and 
facilitate their engagement in the learning process (Wolf, 1993).

\section{Method}

This study is concerned with the context or situated action of using portfolio as an assessment tool in the classroom. It is through this understanding Merriam (2009) the researchers were able to explain the use of portfolio as an assessment tool by the ESL teachers. Since the main objective of this study was to investigate ESL teacher's use of portfolio as an assessment tool in the classroom, hence the use of qualitative method offers greater opportunities for conducting descriptive research that uses the context and setting to search for a deeper understanding of the person being studied (Troudi, 1994, Maykut and Morehouse, 1994; Maxwell, 1996; Silverman, 2000; Radnor, 2001). The learning context is the Malaysian secondary school ESL classroom. This study embarks on a case study which is descriptive in nature and the focus is on a natural setting which is the classroom. It is interested in the meanings, perspectives and understanding by investigating the use of portfolio as an assessment tool by the ESL teachers. The primary data for this study is interviews conducted on nine selected ESL teachers. The research question addressed at this juncture was:

1. How does ESL teachers use portfolio as an assessment tool in the classroom? In this study, ESL teachers who were familiar with portfolio assessment were the teachers who had experienced the process of assessment specifically to track students' learning in the classroom. Participants were purposefully selected through "snowball" or "chain" sampling (Patton, 1990). This approach "identifies cases of interest from people who know, that cases are information rich, that is, good examples for study, good interview subjects" (Patton, 1990, p. 182). For this study, a snowballing sampling technique was employed to choose a sample. This technique was seen most suitable because the researcher could not determine which teachers have had carry out portfolio assessment. The snowballing sampling technique involves asking a participant to refer the researcher to other participants (Merriam, 1998).

\subsection{Semi-structured Interviews}

The interview sessions was carried out with all the nine ESL teachers. The interview was carried out at school staffroom. The researcher sat together with the teachers for the interview. The interview consisted of questions and answers pertaining to the teachers' experience in using portfolio as an assessment tool in their respective classrooms. The interviews with the ESL teachers were carried out twice in a month for a period of two months. The duration of the interviews was between twenty to thirty minutes due to the teacher's workload and other commitments in the school. The aims of the interviews sessions were based on one research question. Firstly, they are intended to get the overall picture and experiences of teachers on the use of portfolio as an assessment tool. As stated by many researchers, the advantage of having semi-structured interview is that it will help the researchers to stay alert to the focus of the study and at the same time be open minded to encounter spontaneous and new ideas that will emerge during the interview sessions (Kvale, 1996; Gillham, 2000; Radnor, 2001; Silverman, 2006). Basically, the interviews in this study focused on one main area which was the use of portfolio as an assessment tool by the ESL teachers. 


\subsection{Observation}

Observation seems to be the most appropriate techniques for getting at 'real life' in the real world. It provided an opportunity to the researchers to record, describe, analyze, interpret and investigate ESL teacher's implementation of portfolio as an assessment tool in the classrooms. According to Robson (2002), observation permits the researchers to watch and listen to the interaction between the teacher and the students.

\section{Findings}

\subsection{Teachers' Understanding of the Purpose, Content and Structure of Portfolio Assessment}

All the nine ESL teachers expressed their concerns that it was necessary to understand the core features of a portfolio assessment before they could use it as an assessment tool to gauge student learning in the classroom. The core features of a portfolio assessment refer to its purpose, content and structure which are considered crucial to bring about effective results of student learning.

\subsection{Purpose of Portfolio Assessment}

A thorough planning is required before teachers could share and train their students about utilizing portfolio as an assessment tool in the classroom. Students need to be informed that portfolio served as a vehicle for learning as well as assessment. The teachers revealed that to execute portfolio assessment, it would require an assessment purpose which is tailored based on the syllabus. At the same time, teachers mentioned that students could be allowed to be involved in setting the assessment purpose based on the learning objectives. By doing so, the teachers believed that students would have something in their minds that they would share with them specifically where learning is concerned. Not all the students were able to share and expressed what they preferred or wanted to learn as they were shy and could not share their views with the teachers.

Researcher: How do you introduce portfolio assessment to your students?

Teacher A At first it was difficult to explain as not all my students could understand the portfolio assessment process.

But, by giving and showing them some examples and guidance, the students are able to do. The students shared some ideas too like which activities to include.

Teacher B I gave students their files. My students were weak at essay, so they knew they have to compile their essays in the portfolios and marks will be given.

Teacher C I give my students some briefing. Students know the activities will be assessed. Students shared their opinions with me too.

Teacher D First, I explain to my students how they are going to use the portfolios.

Teacher E Students are aware that in each lesson, their worksheets would be evaluated. The purpose is not to let students focus on how to answer exam questions. 
Teacher F I had to demonstrate to students first by giving some simple activities then I explained that there is assessment purpose for portfolio assessment.

Teacher G Students understood that they had to compile their worksheets in the portfolios which were then graded.

Teacher $\mathrm{H} \quad$ I give students some explanation the purpose, the content and what to include in portfolio.

Teacher I I give students files, explain about the content of the portfolios.

\subsection{The Contents of Portfolio Assessment}

Apart from this, the teachers pointed out that it was crucial to explain to students specifically about the contents of a portfolio before they could proceed to the other segments of the portfolio. At the beginning, all the teachers faced some difficulties in explaining about portfolio to their students. The teachers solved this problem by giving the students some examples of portfolios and also some guidance. It was found that a clear set of instructions given by the teachers to the students facilitated students' understanding of portfolio.

Researcher: What do the students put in their portfolios?

Teacher A I have the table of content for portfolio. Students compile activities, materials from internet, self-evaluation \& self-reflection

Teacher B Students compile their essays.

Teacher C I have the table of content too. Students put internet articles, biodata, activities, assessment marks, self-reflection \&homework,

Teacher D Students compile their activities which were graded, enrichment activities.

Teacher E Students put their worksheets and self-reflection in the files.

Teacher F Students put their worksheets and self-reflection.

Teacher G Students have their biodata, worksheets, drafts of essays, self-assessment \& self-reflection.

Teacher $\mathrm{H}$ Students put the graded worksheets in the files.

Teacher I Students collect worksheets.

\subsection{Structure of Portfolio Assessment}

It was crucial for teachers to identify objectives of each lesson to ensure the assessment tasks were carefully selected and constructed from other resources in the form of worksheets or activities. Next, the teachers reported that each task/worksheet distributed to students will be evaluated to test student performance at the end of each lesson so that to confirm learning 
objectives were achieved and understood by the students. Teachers would then instruct students to write their self-reflection to enable the teachers to identify the problems students faced in doing their work. Teachers would mark all the activities submitted to them and read student self-reflection. Then, the teachers would provide feedback to help students improve their work. All the works submitted to teachers would then be returned to the students to be kept in their portfolios. Finally, all the student's portfolios will be collected and graded to see their overall performance in the classroom. The portfolio assessment is not only meant to assess students' growth in learning but it assisted teachers to improve and make crucial decisions with regards to their instruction. For this purpose, please refer to figure 1 as it provides a structure of portfolio assessment execution.

\subsection{Classroom Observation}

Guidelines for implementing portfolio assessment

All the nine teachers provided detailed explanation about portfolio assessment to their students. It was crucial for the students and teachers to have portfolios as it involved record keeping. The teachers allowed students to compile materials from the internet and magazines to make learning more meaningful. Yancey (1992) supports the notion that portfolios should be designed by teachers and students. Portfolio assessment aids in stimulating thinking and promoting student independence (Thomas, C, Blackbourn, J. M, Britt, P, Blackbourn, R, Papason, B \& Tyler, J. L, 2005). The students were informed about the purpose of the portfolio assessment as the teachers were interested in monitoring students' progress in learning and students' contribution during classroom discussion. The teachers provided a checklist/table of content to students so that students would have an idea about the appropriate materials for the portfolios. After each lesson, the teachers distributed extra activities to the students which they have to compile it in their portfolios. The students were allowed to choose the best work with the highest marks which display their ability in a certain topic. Next, students filled-in the self-assessment forms to indicate how much learning has taken place and the problems they encountered while doing the activities and then students were asked to write in their self-reflection. Students were required to collect and compile other activities which reported on their development in learning from time to time. The following is an example of the checklist/table of content of a portfolio given to the students:

i) student's information, photos, \& learning goals

ii) samples of student's best worksheets

iii) self-assessment \& self-reflection

iv) materials from internet $\&$ magazines by the students

In the following lesson, the teachers provided feedback to students based on their self-reflection. Students' reflection is one of those features which have been highlighted (Lynch \& Shaw, 2005). Moreover, teachers provided constructive feedback to students based on their reflection so that students can be engaged in the assessment process. They spent some time with students explaining thoroughly on ways students can improve learning based 
on the topics the teachers had taught. Students were given many opportunities to speak and share their ideas about the assessment activities the teachers gave them in the classroom. The teachers returned the portfolios to the students and asked the students to check the documents compiled and insert their self-reflection into the portfolio. Students started discussing with their friends and showing their portfolios to one another. The following table summarized how the nine teachers conducted their lessons based on the researchers' observations.

Teacher A Did some explanation about the topic \& had two-way communication with her students.

After teaching she distributed worksheets to her students. Did not do self-assessment with her students. She reminded the students to write self-reflection.

Teacher B Used questioning technique, mind-mapping \& power-point slides to conduct her lesson.

She distributed worksheets to the students. Students filled in self-assessment form. She asked her students to submit self-reflection. Students did peer-assessment and were guided by the teacher. (A trip to Melaka)

Teacher C She read the text aloud followed by the students. Used bilingual to teach as her students were weak. The teacher did the activity together with the students. Teacher gave self-assessment form to students.

Teacher D She drew some pictures before she could start teaching.

Teacher E The students put up an acting and the whole class guessed what the lesson was all about. Then, the teacher started with her explanation about the lesson. The teacher asked students to present. The students work in groups of four. The teacher distributed worksheets to the students. The teacher distributed self-assessment form to students. She reminded the students to write self-reflection.

Teacher F Did not do any explanation. She distributed some notes to the students. The students read. The students were asked to get into groups of four. They discussed and the teacher gave out the self-assessment form to the students. She reminded students to write self-reflection.

Teacher G She taught her class by giving some explanation. Then, worksheets were distributed. Students copied learning outcomes from the board and the teacher asked students if they had understood what she taught.

Teacher $\mathrm{H}$ She taught her class by giving some explanation. Then, worksheets were distributed. Students copied learning outcomes from the board and the teacher asked students if they had understood what she taught.

Teacher I She taught her class by giving some explanation. Then, worksheets were distributed. Students copied learning outcomes from the board and the teacher asked students if they had understood what she taught. Did not do self-reflection with the students. 


\subsection{Interviews with the Teachers}

The teachers disclosed that portfolio assessment offers viable alternative to traditional tests. The teachers were able to assist weak and passive learners to improve their learning in English. The weak and passive learners showed some interest in learning as they were aware of the grades that would be awarded if they participate during classroom discussion, completing worksheets and compiling materials in the portfolios. The teachers distributed 2-3 worksheets to students every week and allowed students to choose worksheet with the highest marks to be kept in their portfolios. For each worksheet with the highest mark, the teachers awarded and recorded one mark. Each student's portfolio carries $20 \%$ based on the following: (personal, 2\%), (academic, 2\%), (assessment/worksheets, 14\%) and (appendix, 2\%). There were 14 worksheets all together. Worksheets with lower marks were also compiled but marks were not given. The teachers were able to assess and track progress students make in learning via the marks students collected based on the worksheets. The student's self-assessment form informed teachers about students' understanding and conceptualisation in learning. When students were involved in the self-assessment activity, they were able to inform their teachers specifically about the learning outcomes that they have understood. The teachers' interview data revealed that student self-assessment helped teachers to understand the problems students faced in learning English. The self-assessment is designed based on the learning objectives that had to be achieved by each and every student in the class. So, when students submit their self-assessment form to their teachers, teachers were able to track the problems students faced in learning. This opportunity supported teachers in terms of understanding the weaknesses of their students and allowed teachers to be resourceful and creative in assisting weak learners. Based on the teachers' feedback and interview, the researcher was able to come up with the following contents of portfolio for collection of evidence.

Researcher How do you conduct the portfolio assessment process in your classroom?

Teacher A after teaching a topic, I usually grade the student's work. I award marks to students to motivate them.

Teacher B Students put their work in the file and assess the work. I grade students' writing. I asked the students to do the peer-assessment. I could see the competition among the students. Students checked their grade from time to time to see if they have improved.

Teacher C The rubrics were clear to students to do the work. I encourage students to include articles from internet, magazine. I assess them once in a week. I asked students to put homework, test papers and articles in the file.

Teacher D I mark students' worksheets and grade them. I am able to see their strengths and weaknesses.

Teacher E The worksheets given are given marks and kept in the file.

Teacher F students are assessed in the lesson and we have to keep the worksheet assessed inside the file as evidence 
Teacher G Each student is given worksheet and I mark and grade their work. The worksheets are put in the file.

Teacher H I distribute worksheets to students, then they are graded and kept in the file.

Teacher I Not all the students submit their work. Sometimes its difficult to collect. I collect worksheets from students to grade. Students will put the worksheets in the file.

\subsection{Student Self-assessment}

The teachers divulged that there were two core features of a portfolio assessment student self-assessment and student self-reflection. A portfolio assessment would be incomplete without these two features. The teachers' interview data revealed that student self-assessment helped teachers to understand the problems students faced in learning English. The self-assessment is designed based on the learning objectives that had to be achieved by each and every student in the class. So, when students submit their self-assessment form to their teachers, teachers were able to track the problems students faced in learning. This opportunity supported teachers in terms of understanding the weaknesses of their students and allowed teachers to be resourceful and creative in assisting weak learners. For example, as in the case of Teacher A, she shared that via student self-assessment form, she was able to come up with two different kinds of activities for her students. She mentioned that student self-assessment allowed her to scrutinize student progress in learning and at the same time she was able to divide students into two groups; group A (weak students) and group B (good students) where she would prepare extra activities to helped them improve their learning. The chart below indicates that how (Teacher I) identifies good and weak students through portfolio assessment which she felt was useful for her to improve teaching and learning process in the classroom.

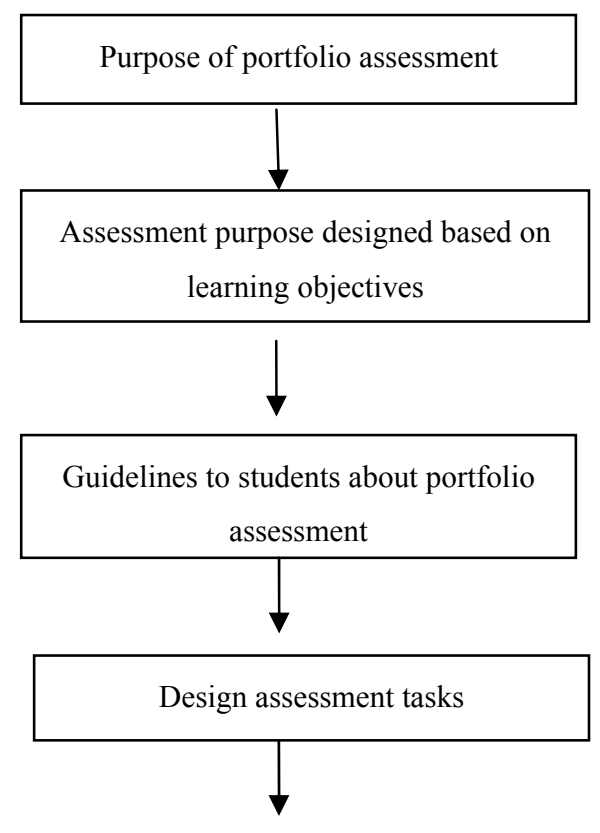




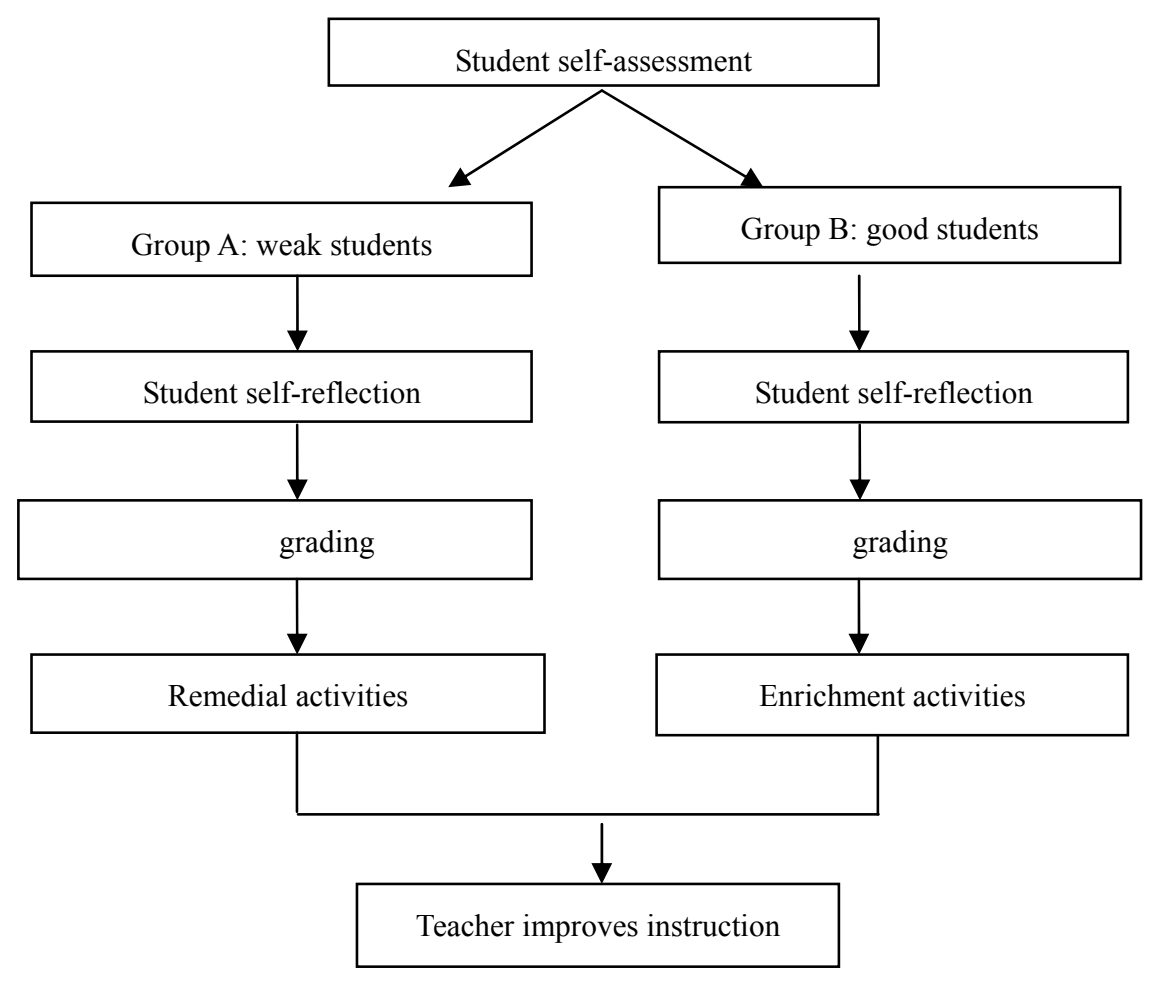

Figure 1. structure of using portfolio as an assessment tool by Teacher A

\subsubsection{Student Self-reflection}

The teachers revealed that portfolio assessment would be incomplete without students' self-reflection as it informed teachers their students' strengths and weaknesses in specific areas of learning. Student self-reflection served as a platform for teachers to further delve into student present state of competence and their understanding in learning English. Teachers were able to see if the students have achieved the learning objectives via student self-reflection. Teachers also reported that not all the students were able to produce self-reflection due their inability to write well. Below are some examples of the comments teachers shared with the researchers:

Researcher So after each lesson, is there a self-reflection done by the students?

Teacher A Students do self-reflection after each lesson to reflect what they have learnt. Some students write about their problems specifically to share they don't love literature but with portfolio, the students started showing some interest as they do lot of worksheets.

Teacher B When I read the reflection, I know what students' weaknesses in writing are. They want to improve their sentence construction and learn more vocabulary.

Teacher C Some students cannot write the reflection because they are very weak but they still try. The students like the activities very much and suggested to have more activities as it improved their learning. 
Teacher D They do the reflection and peer-evaluation to see their strengths and weaknesses.

Teacher E From their reflection, I know that they prefer different method of teaching which is more student-centred.

Some of them are very shy and afraid to write.

Teacher F From the reflection, I found out students preferred language games and I designed my lessons based on students' needs. I gave to guide them for their reflection.

Teacher G Students write they love the lesson and activities as they get marks. Not all the students can write well.

Teacher H Students share what they know and what they don't know while learning English.

Teacher I I didn't do reflection with the students. When students do their self-assessment, they write about what they have learnt in my lesson. They write some notes on self-assessment forms.

In other words, the teachers felt that it was not easy to convince students to write their self-reflection as it required students to write conscientiously about their strengths and weaknesses while learning and achieving the learning objectives. Some students just shared their views with teachers when their names were called out individually and even by doing so the teacher mentioned she could still record students' problems in mastering English in the classroom.

\section{Discussion}

In observations and interviews with the teachers regarding the use of portfolio as an assessment tool, the main concern was to internalize core features of a portfolio assessment before they could use it as an assessment tool to gauge student learning in the classroom. Portfolio assessment improves students' learning through the worksheets that they do in the classroom which is fun. Before the lesson ends, teachers ask students to fill in the self-assessment form by asking them what they have learnt about the topic and what they would like to know by the end of the lesson. By doing so, it helps students to stay focused and interested during the lesson and gives them a sense of accomplishment when they write self-reflection for following the lesson and realize that they have learned something. All this contributes to students' academic growth. To gain multiple perspectives on students' academic development, the teachers instructed students to include more than one type of material in the portfolio.

Portfolio assessment increases student motivation for learning as they are often enmeshed in constant self-reflection and self-assessment. Students don't just put the materials into the portfolio, they have to reflect upon the material, what they learned from the worksheets, and why are they placing the material into the portfolio. The students described that if they don't 
understand something, self-reflection serves a medium and a diary for them to tell the teacher what their problem are. After reading student self-reflection, the teacher would then provide some feedback to problems students face in learning by giving some alternatives in the form of remedial activity. The assessment process in portfolio allows students to participate actively in group discussion and also share some constructive ideas with their peers. In other words, students do not only communicate with their peers in the class during group discussion but they are allowed to make affective communication with their teachers too. Portfolio assessment does not only allow students to discover their own learning but it allows students to evaluate their own strengths and weaknesses. It provides an opportunity for students to demonstrate his/her strengths as well as weakness concurrently. When students are aware that they evaluating their own strengths and weaknesses, it also encourages students to take responsibility for their own learning, and enhance student-teacher communication.

\section{Conclusion}

Based on the findings of the current study, ESL teachers found the use of portfolio as an assessment tool beneficial as it allowed both teachers and students to collaborate in the teaching, learning and assessment process. According to Paulson, Paulson \& Meyer (1991), portfolio assessment provides the teachers and students an opportunity to observe students in a broader context: taking risks, developing creative solutions, and learning to make judgments about their own performances. Adams (1998) asserts that portfolio presents a wide perspective of learning process for students and enables a continuous feedback for them. This is further supported by De fina (1992) as portfolio enables students to have a self assessment for their studies and learning, and to review their progress. In sum, this study suggested that portfolio assessment is a useful tool in documenting students' overall learning process, improve students' motivation and confidence for learning and thus achievement in English. Portfolio assessment has the potential to provide a platform for student-teacher dialogue to improve instruction.

\section{References}

Abdul Samad, A. A. (2004). Essential language testing for Malaysian teachers. Kuala Lumpur: Malindo Printers Sdn Bhd.

Adams, T. L. (1998). Alternative Assessment in Elementary School Mathematics. Childhood Education, 74(4), 220-224.

Apple, M., \& Shimo, E. (2004). Learners to teachers: Portfolios please! Perceptions of portfolio assessment in EFL classrooms.

Anderson, D. S., \& Piazza, J. A. (1996). Changing Beliefs: Teaching and Learning Mathematics in Constructivist Pre-service Classroom. Action in Teacher Education, 18(2), 51-62.

Bufkin, L. J., \& Bryde, S. (1996). Implementing a Constructivist Approach in Higher Education with Early Childhood Educators. Journal of Early Childhood Instructor Education, $17(2), 58-65$. 


\section{Macrothink}

International Journal of English Language Education

ISSN 2325-0887

2013, Vol. 1, No. 1

Coombe, C. (2004). The reflective portfolio: Two case studies from the United Arab Emirates. English Language Forum.

Chang, M. Y. (2001). Application of portfolio assessment in Education from the view of Multiple Intelligences. Educational Research Information, 9(1), 32-54.

Chen, Y. M. (1999). A portfolio approach to EFL university writing instruction. Proceedings of the $16^{\text {th }}$ National Conference on English Teaching \& Learning in the Republic of China (313-332) - Taipei: Crane Publishing Co.

Chen, Y. M (2000). Learning writing as writers: A portfolio writing curriculum for EFL University first-years students. Proceedings of the $16^{\text {th }}$ National Conference on English Teaching \& Learning in the Republic of China (294-309) - Taipei: Crane Publishing Co.

Chen, Y. M. (2006). EFL instruction and assessment with portfolios: A case study in Taiwan. Asian EFL Journal, 8(1), 69-96.

Dai, W. Y. (2003). Multiple Intelligences and English Teaching. Taipei: Shi Da Book.

Davydov, V. V. (1995). The Influence of L.S. Vygotsky on Education Theory, Research and Practice. Education Researcher, 24(3), 12-21.

De Fina, A. (1992). Portfolio Assessment: Getting Started. New York: Scholastic Professional Books.

Duckworth, E. (1987). The Having of Wonderful Ideas. New York: Instructors College Press.

Elahinia, H. (2004). Assessment of writing through portfolios and achievement tests. Unpublished M.A. thesis, Teacher Training University, Iran.

Fahed, Al-Serhani, W. (2007). The effect of portfolio assessment on the writing performance of EFL secondary school students in Saudi Arabia. Unpublished M.A Thesis, Taibah University, Saudi Arabia.

Far, F., \& Tone, B. (1994). Portfolio and Performance Assessment: Helping students evaluate their progress as readers and writers. Fort Worth, TX: Harcourt Brace College Publishers.

Fosnot, C. W. (1996). Constructivism: A Psychological Theory of Learning. In C. W. Fosnot (ed.), Constructivism: Theory, Perspectives, and Practices. New York: Teachers College Press.

Gottlieb, M. (1995). Nurturing student learning through portfolios. TESOL JOURNAL, 5(1), 12-14.

Gruencher, C. D. (1996). Constructivism and Learning. A Philosophical Appraisal. Educational Technology, 36(3), 21-29.

Kemboja Ismail. (2009). Portfolio as an assessment tool in a Malaysian classroom. A case study. Unpublished doctoral dissertation. Universiti Kebangsaan Malaysia.

Kroll, L. R., \& LaBosky, V. K. (1996). Practicing what we Preach: Constructivism in a 


\section{Macrothink}

Teacher Education Program. Action in Teacher Education, 18(2), 63-72.

Kvale, S. (1996). Interviews: An Introduction to qualitative research interviewing. Thousand Oaks: Sage Publications.

Maxwell, J. A. (1996). Qualitative Research Design: An Interactive Approach. London: Sage Publications.

Maykut, P., \& Morehouse, R. (1994). Beginning Qualitative Research. London: Routledge Falmer.

Merriam, S. B. (1998). Qualitative research and case study applications in education. San Francisco: Jossey-Bass.

Moya, S., \& O’Malley, J. M. (1994). A portfolio assessment model for ESL. The Journal of Educational Issue of Language Minority Students, 13, 13-26.

Neiman, L. V. (1999). Linking theory and practice in portfolio assessment. Retrieved on May 12, 2012, from WEAC, Website: http//:www.weac

Paulson, F. L., Paulson, P. R., \& Meyer, C. A. (1999). What makes a portfolio Educational Leasership, 48(1), 60-63.

Patton, M. Q. (1990). Qualitative evaluation and research methods (2nd ed.). Newbury Park, CA: Sage.

Radnor, H. (2001). Researching Your Professional Practice: Buckingham: Open University Press.

Smolen, L., Newman, C., Wathen, T., \& Lee, D. (1995). Developing student self-assessment strategies. TESOL JOURNAL, 5(1), 22-27.

Tabatataei. (2012). The Effect of Portfolio Assessment Technique on Writing Performance of EFL Learners. English Language Teaching, 5(5).

Tunku Mohani Tunku Mohtar. (2010). The use of alternative assessment to sustain teaching and learning. Penerbit UPSI.

Troudi, S. (1994). The Nature of Speaking Opportunities in An English As a Second Language Speaking Class. University of Florida: Unpublished $\mathrm{PhD}$ Thesis.

Yeh, H. N. (2000). Multi-dimensional assessment for the English Subject in Grade 1-9 Curriculum. English Teaching and Learning, 24(3), 5-28.

\section{Copyright Disclaimer}

Copyright reserved by the author(s).

This article is an open-access article distributed under the terms and conditions of the Creative Commons Attribution license (http://creativecommons.org/licenses/by/3.0/). 